\title{
The Changes Need in the Educational System in the Czech Republic (and Maybe Not Only There)
}

\author{
Liběna Kantnerová \\ University of South Bohemia, České Budějovice, the Czech Republic
}

\begin{abstract}
This paper analyses the need to deal with the issue of financial literacy and financial knowledge. This paper is focused on researching into the knowledge and understanding of the financial literacy of young people and ways leading to improving of the situation. The survey, undertaken in the Czech Republic, is based on a sample of students (in total 432) in part of South Bohemia. In the Czech Republic, there can be seen poor legislation, aggressive advertising and behaviours, low professionalism in some financial institutions, and fraud on one side and debts and problems on the other.
\end{abstract}

Keywords: financial literacy, financial behaviour, educational system

\section{Introduction}

In recent years, developed and emerging countries and economies have become increasingly concerned about the level of financial literacy of their citizens. This has stemmed in particular from shrinking public and private support systems, shifting demographic profiles including the ageing of the population, and wide-ranging developments in the financial marketplace. Concern was also heightened by the financial crisis, with the recognition that lack of financial literacy was one of the factors contributing to ill-informed financial decisions and that these decisions could, in turn, have tremendous negative spill-over effects (OECD, 2011). As a result, financial literacy is now globally acknowledged as an important element of economic and financial stability and development (INFE, 2009). There are lots of changes after the introduction of lots of new financial products (Zandi, 2008). The securitisation of debts came to being the financial instruments for anybody, there are lots of difficulties and exotic financial instruments in the market (Lucas, Goodman, \& Fabozzi, 2007).

But individuals are increasingly in charge of securing their own financial well-being mostly after retirement. With the shift from defined benefit to defined contribution pensions, today's workers have to decide both how much to save and how to allocate their retirement wealth. Financial markets have become more complex and individuals are faced with a proliferation of new investment products, many of which are new and often fairly complex. Investment opportunities have expanded beyond national borders, permitting individuals to invest in a broad range of assets and currencies. However, as the financial crisis has made it clear, it is very hard to navigate this new financial system and the consequences of mistakes can be devastating. But how well individuals are equipped to make financial decisions and how much do individuals know about economics and

Liběna Kantnerová, Ph.D., Department of Finance and Accounting, University of South Bohemia, České Budějovice, the Czech Republic.

Correspondence concerning this article should be addressed to Liběna Kantnerová, Studentská 13, 37005 České Budějovice, the Czech Republic. 
finance (Renaud, 2009) emphasizes that for the first time in the world history more people live in urban areas than in rural areas. As a result, financial system connected with housing becomes more and more important part of the whole economy. Housing loans will increase, because urban expansion intensifies. This cannot be covered by government expenditures solely. On the other side, it can notice that the traditional role of a bank as a lending institution declines. Household savings are not invested in banking deposits because of the offered profit (rate).

Even with little personal knowledge, individuals can avoid making financial mistakes by consulting with more knowledgeable individuals, including financial professionals. It is not enough to recognise that financial knowledge is low; people must also understand whether financial literacy matters in decision-making. Addressing this question is particularly difficult because financial literacy is not distributed randomly in the population: those who possess high levels of literacy are likely to possess characteristics, such as high talents and ability, or patience, which are also correlated with financial decision-making. Moreover, individuals may choose to invest in gaining financial knowledge; thus, financial literacy itself can be a choice variable and it may be those who have high wealth, rich pensions, or investments in financial markets who care more about improving their financial knowledge. Knowledge sharing plays important role in work on the latest development projects, in improvement team performance, in improvement of innovation capabilities and business performance, including sales growth and —of course — the personal life of workers (Maroušek, Zeman, Vaníčková, \& Hašková, 2014).

\section{The Situation in the Czech Republic}

The Czech banking sector is under great evolution since 1989. Not only globalisation processes intensified, but also a transition in economy had started. Some of banks were privatised, after Czech banking crises play, here and now, the most important role of foreign capital.

Nowadays is the situation changing everywhere. The financial crisis after 2008 and following economic crisis, leader banks decreased price of money. People in the changing society wanted to reach as soon as possible the level of West-European countries in the life style and the situation leaded them from the conservative behaviour of the Czech citizens in the past to the general mention - it is better to have loans than to save money now, it is showed in Figure 1.

From Figure 1, it is clear that people in the Czech Republic in the last years found the best investment in the mortgage - the level of finance borrowed from banks is growing from year to year. In the beginning of 2016, the level is more than one billion (1.4) CZK (rate-27 CZK for one EUR or 23 for one USD). Mortgages are the best loan from the point of any financial specialist. The level of mortgages is all the time growing without any respect to crisis or recession. All other loans are stagnated after the crisis, what can be taken as good signal of the improvement of the situation in the level of financial literacy in the Czech Republic?

The specific nature of Czech society in the area of financial literacy is strictly correlated with the socio-economic changes that have occurred since 1989. It was the development of the free-market economy that forced the government and financial institutions to increase their interest in financial literacy. The other historical event having a significant impact on financial literacy was Czech's entry to the European Union and, connected with that, the necessity of ratifying certain acts. There are too many new products in the financial markets and — unfortunately — the moral of new based companies in this field is not the best. 


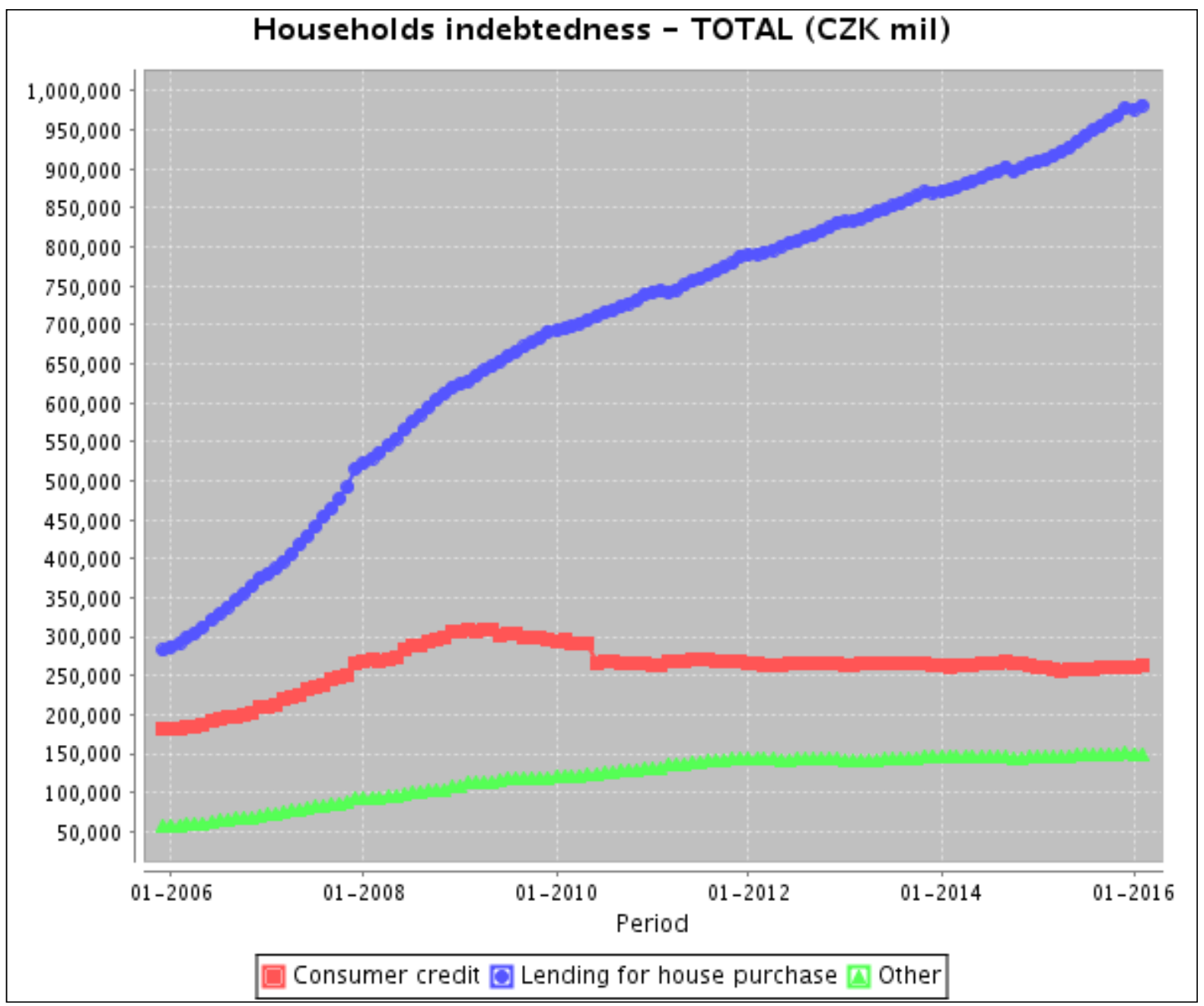

Figure 1. Total debt of citizens of the Czech Republic published on web pages of the Czech National Bank.

In the education and protection of the Czech citizens, the crucial role in shaping financial literacy should be played by the National Bank of the Czech Republic and realised in co-operation with the public and private sector through government and self-government institutions, professional, and customer communities as well as infrastructure institutions of the financial market. In financial education, it is necessary to co-ordinate activities to set objectives, educational standards, and to encourage non-government organizations to participate in a program of raising the financial literacy of Czech citizens, partially supported with public funds. Focus on this aim is paid by media, too.

Parents of children and youth in the Czech Republic and associated countries in the Eastern part of the Europe have different experiences and education and they are not comparing to new rules and products, too much news in the markets is coming. Parents are fully oriented to their job and don't have enough time to raise their children. The role of financial education is going over to school and other state institutions. Four ministries are involved now-Ministry of Education, Finance, Labour, and Justice. This is attested by the dynamic growth of property seizures to over 300 thousand annually — naturally, some of these were attributed to the development of legislation and the solution of comparatively insignificant liabilities arising from various finesses; nevertheless, the amount of resources in seizure rulings is gradually increasing (Paseková \& Ředinová, 
2012). In 2012, it was each tenth citizen of the Czech Republic. Similarly, the amount of registered loan agreements is dynamically increasing in general and people should take into consideration the fact that more than 150 thousand families currently have serious difficulties in fulfilling their obligations (Smrčka, 2008).

The situation in the education looks as follows.

\section{Financial Education in the Czech Republic}

In the Czech Republic, the Ministry of Finance (2010) has started to discuss financial education within the care of consumer's protection in the financial market. Based on the recommendations of the publication Improving Financial Literacy, a document Strategie Finančního Vzdělávání (Strategy of Financial Education) (Ministry of Finance of the ČR, 2007) was published as well as its updated version NárodnÍ Strategie Finančniho Vzděláváni (National Strategy of Financial Education) was published in 2010. The aim of the strategy, which is presented in this document, is an integrated system of financial education, which would help increasing the level of financial literacy in the Czech Republic. The proposed action is based on two pillars - initial education (preschool, primary, secondary, and higher education) and further education (educational activities focused on the adult population that are not within the initial training). This chapter should focus on initial education. The document Strategie finančního vzděláváni followed by a document Systém Budováni Finanční Gramotnosti na Základnich a Střednich Školách (The System of Creating Financial Literacy in Primary and Secondary Schools) (MŠMT, 2007) was created together by the Czech Ministry of Finance (MF), the Ministry of Education, Youth and Sport (MŠMT), and the Ministry of Industry and Trade (MPO) on behalf of the Government of the Czech Republic. This document defined the standards for financial literacy for three different target groups:

- Standard financial literacy for the first stage of primary schools (age 6-10).

- Standard financial literacy for the second stage of primary schools (age 11-15).

- Standard financial literacy for secondary schools (age 16-19) — corresponding to the standard of an adult person.

Standards for those target groups include the following areas: money, management of household and financial products. The standard of financial literacy for secondary education also includes the topic of consumer rights. Their contents would be discussed below:

- Standard of financial literacy for the first stage of primary schools.

(1) Money

Content: Cash and non-cash forms of money, methods of payment, and a bank as a money manager.

Outputs: A student who uses money in common situations estimates and checks the purchase price and the charge.

(2) Household management

Content: Budget, income, household expenses, and eligibility to make a claim.

Outputs: A student can say with examples why it is not possible to implement all wanted spending.

(3) Financial products

Content: Savings and loans.

Outputs: A student can explain why to save money when to borrow and how to return debts.

- Standard of financial literacy for the second stage of primary schools.

(1) Money 
Content: Money management, production rates, and inflation.

Outputs: A student can show with examples the appropriate use of various instruments of cash and cashless payment. Also, they can show the formation of prices as the sum of the cost, profit, and value added tax (VAT). A student can explain the influence of supply and demand on the formation of prices and their changes, and describe the impact of inflation on the value of money.

(2) Household management

Content: Household budget, budget types, and their differences.

Outputs: A student can draft a simple household budget with the most important income and expenses, distinguishing among regular and one-off income and expenses and consider the necessity of individual expenditures. Furthermore, a student can illustrate the principle of a balanced, deficit, and surplus, and explain how to defend themselves in case of violation of consumer rights.

(3) Financial products

Content: Services of banks. Active and passive operations, financial market products for investment and to obtain funds, insurance, and interest.

Outputs: A student can give examples of the use of debit and credit cards. They can explain their limitations. Furthermore, a student can define and compare the most common ways of dealing with free resources (consumption, savings, and investment), and the most common ways to cover the deficit (loans, hire purchase, and leasing), explain the significance of interest paid, and receive and indicate the most common types of insurance, and suggest how to use them.

- Standard financial literacy for secondary schools

(1) Money

Content: Payment in national and foreign currency, pricing, and inflation.

Outputs: A student uses the most common payment instruments. They are able to exchange money using the exchange rate; they can determine the price as the sum of the cost, profit, and value added tax (VAT). Additionally, students can explain how the price varies by customer, location, season, etc. Recognize common price tricks (excluding VAT...) and misleading offers. They can explain the nature of inflation and its impact on the incomes of the population, deposits, loans, and long-term financial planning. They provide examples of how to struggle with the consequences of inflation.

(2) Household management

Content: Household budget.

Outputs: A student can distinguish among regular and irregular income and expenditure and on the basis of this resolution they can define the household budget. A student suggests how to solve the budget deficit and how to deal with the budget in surplus household.

(3) Financial products

Content: Surplus funds, lack of funds, and insurance.

Outputs: A student will propose utilizing of available financial resources (savings products with state contributions, securities, real estate...). They can choose the best product for the investment of available funds and explain why. They can select the best loan product based on their needs and justify the choice. They can judge the ways of securing a loan and explain how to avoid over-indebtedness. They can explain methods for determining interest rates and the difference between the interest rate and annual percentage rate (APR). They can select the best insurance product with regard to their needs. 


\section{(4) Consumer rights}

Content: Consumer protection law, content of contracts.

Outputs: A student can explain with examples how to apply the rights of the consumer (when purchasing goods and services, including financial market products). They can show the possible consequences of ignorance of the contract including the general conditions.

All of these standards of financial literacy have been implemented into the curricula documents of Czech educational system, which are the Framework Educational Programs (FEP) for different levels and types of schools. Full integration into the FEP for grammar schools and secondary vocational schools was implemented during 2008 and 2009. The standards were implemented into educational areas "Man and the World of Work" and "Mathematics and its Applications".

The outputs and issues of the programmes related to financial literacy are discussed below.

Man and His World/People around us (VUP, RVP ZŠ, 2013), first stage of primary education:

Outputs: A student is familiar with the basic forms of ownership. They use money in everyday situations, and estimate and check the price of purchase and charge, they can show the impossibility of the realization of wanted expenses, explain why to save money, when to borrow, and how to return debts.

Curriculum: Law and Justice - the legal protection of citizens, including the right to complain. Ownership - private, public, private, joint, and tangible and intangible assets. Budget, income, and household expenses; cash and non-cash form of money, payment methods; bank as money manager, savings, and loans.

Man and Society/Citizenship Education/People, State, and Economy (VUP, RVP Ž̌, 2013), second stage of primary education: Outputs: A student can

- distinguish between different forms of property, including intellectual property, and methods of their protection

- draft a simple household budget, provide the main income and expenditure, distinguish regular and one-off income and expenses, consider the necessity of individual expenditures in household management, illustrate the principle of a balanced, deficit and surplus household, comply with the principles of economy, and avoid risks in money management

- show with examples appropriate use of various instruments of cash and non-cash payment, give examples of the use of a debit and credit card, and explain their limitations

- explain the role of banks and the services they provide, explain the significance of interest paid and received, list the most common types of insurance, and suggest when to use them

- state and compare the most common ways of dealing with free resources and ways to cover the deficit

- explain the fundamental function of the market with an example of the behaviour of buyers and sellers, illustrate the influence of supply and demand on the formation of prices and their changes, the formation of prices as the sum of costs, profits, and VAT, and describe the impact of inflation on the value of money

- distinguish the sources of state revenues and areas of state expenditures, provide examples of allowances and benefits for citizens from the state budget

- distinguish among the roles of production, trade, and services, provide examples of their cooperation

Curriculum:

- property ownership - ownership forms; material and intellectual property and its protection; money management, property, and various forms of ownership

- money-functions and forms of money, methods of payment

- economy - household budget, savings, investments, loans, hire purchase, and leasing; national budget, budget types, and their differences; the importance of taxes

- banks and their services - the active and passive operations, interest, insurance, and financial market products for investment and fundraising

- production, trade, and services - their function and continuity

- the principles of the market economy - supply, demand, and market; creating price inflation; the essence of the functioning of the market; the most common legal forms of business

Man and Society/Citizenship education/People, State and law (VUP, RVP ZŠ, 2013), second stage of primary education:

Outputs: A student can reasonably assert their rights, including the right of a consumer. They can perform simple legal procedures and understand their implications, give examples of agreements regulating civil relations-personal transport; purchase, repair, or hire.

Curriculum: Right in everyday life - the importance of legal relations; important legal relationships, and obligations arising there from; basic consumer rights; contact with authorities. 
As discussed above, there is a relation between content and financial and mathematical literacy.

Important parts of the area of "Mathematics and its Applications" from the FEP for primary education related to dealing with financial problems are cited below.

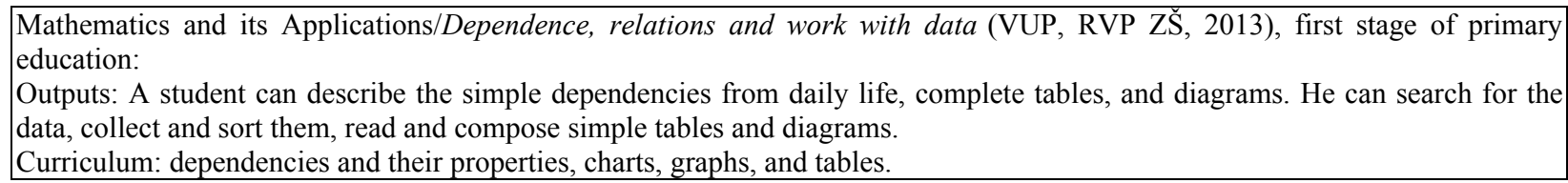

Mathematics and its Applications/Nonstandard application tasks and problems (VUP, RVP ZŠ, 2013), first stage of primary education:

Outputs: A student can solve simple word problems and practical problems, their solution is largely independent of the normal procedures and algorithms of school mathematics.

Curriculum: Word problems, numbers, and image series.

Mathematics and its Applications/Number and variable (VUP, RVP ZŠ, 2013, str. 32), second stage of primary education:

Outputs: A student can solve applied problems using percentage (even if the percent is greater than the whole). They can apply mathematical form to simple real situations using variables; formulate and solve real-life situations using equations. They can analyze and solve simple problems and specific model situations using mathematical tools.

Curriculum: Ratio - scale, proportion, rule of three. Percent—percent, per mille; basis of the percentages, percentage; simple interest. Expression-numeric expression and its value; variables, expressions with variables, and polynomials. Equations-linear equations.

Mathematics and its Applications/Dependence, relations and work with data (VUP, RVP ZŠ, 2013), second stage of primary education:

Outputs: A student can seek, evaluate, and process data. They can compare data sets. They can determine direct or indirect correlation. They can express functional relationship using tables, equations, and graphs. They can apply mathematical form to simple real situations using functional relations.

Curriculum: dependencies and data-examples of dependencies from everyday life and their properties, drawings, diagrams, charts, graphs, and tables. Function — direct and indirect correlation, linear function.

Mathematics and its Applications/Nonstandard application tasks and problems (VUP, RVP ZŠ, 2013), second stage of primary education:

Outputs: A student can use logical consideration and combinatory logic to solve tasks and problems and find different solutions to presented or analyzed situations. They can apply and combine knowledge and skills from various thematic and educational areas.

Curriculum: Logical and unusual tasks.

\section{Problem Formulation}

There has been a lot of debate about the definition of financial literacy and many definitions are accepted.

The INFE has defined financial literacy as follows: a combination of awareness, knowledge, skill, attitude, and behaviour necessary to make sound financial decisions and ultimately achieve individual financial wellbeing.

Because of the situation that financial literacy is increasingly considered to be an essential life skill, the focus of OECD is from 2005, when the OECD Recommendation advised that "financial education should start at school. People should be educated about financial matters as early as possible in their lives".

There are lots of activities targeted to the search and evaluation of the level of financial literacy by youth.

\section{Methodology}

Research was based on a survey of 259 secondary school students, in five different high schools, and 173 university students, from three different faculties of the University of South Bohemia in České Budějovice by means of a questionnaire. Statistical methods were used for its evaluation. The questionnaire contained some 
shortened versions of questions used by the Ministry of Finance of the Czech Republic. Furthermore, respondents were questioned about their sources of information regarding managing money. Their "knowledge" was assessed according to their answers to the questions.

Results were evaluated by the method used by Braak and Šmilauer (2002): CANOCO Reference Manual and Cano Draw for Windows User's Guide: Software for Canonical Community Ordination (version 4.5), Microcomputer Power, Ithaca, New York.

The calculation was made by the CANOCO program for Windows (Braak \& Šmilauer, 2002), STATISTICA and StatSoft, Inc. (Braak \& Šmilauer, 2010). STATISTICA (data analysis software system), version 9.1 .

Data were collected in five high schools and four different universities (University of South Bohemia in České Budějovice) — each with a different area of study—in the Czech Republic town of České Budějovice. The participants were selected by way of random choice by agreements with the management of schools and teachers of financial subjects.

\section{Results and Summary}

In České Budějovice, the Czech Republic, 259 high school students and 173 college students from the University of South Bohemia participated in the survey. It is interesting to note that the relationship between knowledge and the extent of interest in financial education is not as great as expected. The biggest differences are seen in the responses regarding knowledge of the household budget, whereby the lowest levels of knowledge were found in high school students who were without a strong economic education.

Criteria for choosing a bank-There are very comparable answers between the two types of schools with the exception of electronic banking. Students from University chose this more often, probably because of the easier availability of personal computers (PCs) for them. For university students, it is a more practical option. They often have their own bank account and manage their own money themselves. Both groups are focused on the cost of an account, such as fees and credibility of the bank. The focus on fees is a positive trend as is, also, credibility. This is probably due to how they were raised by their families, as they may recall the bankruptcies of many Czech banks in the 1990's.

Criteria for choosing a credit line-There is a clear focus on cost once again. If the summary of the three answers focused on cost will be done, there is a ratio between high school students and university students of $75: 86$. The higher level of education is probably the reason for the disproportion in answering to the question about knowledge of Annual Percentage Rate of Charge (APRC), which is 21:56. In the comparison of the results of the Ministry of Finance, there is a disproportion of 75:86 (students):58. This can be perceived as evidence of the impact of higher student education.

Household budget - A better level of knowledge is displayed by university students, since $82 \%$ answered positively. University students are older and can also have their own bank account (according to Czech law) and very often they have a part-time job or help their family to pay for their education and better themselves, so they would be more familiar with managing money and budgeting. In the comparison with the results of the Ministry of Finance, there is disproportion of 82:75 (students):37. This would seem to indicate strong evidence for the impact of higher student education.

Before signing of the agreement-In both groups of respondents, there are some unexpected answers since the ratio is 9:11. There were no university students who answered "I do not know". In the current situation in 
the Czech Republic, it is strongly recommended to read very carefully the full agreement because of the decreased level of professional and moral behaviour of financial institution employees. Again, there is a better level of knowledge by the university students.

Penalties if loan is not paid-The ratio 85:96 tells that again the level of education has an impact on the thinking and knowledge of students and that educational level is an area of focus.

Insolvency (default) - The highest awareness is, again, students with higher education levels. However, there are warning signs from the answers of high school students. For example, 19\% do not know what they should do in the event of insolvency. In this situation, they are vulnerable to credit traps. This group is the most susceptible to credit and financial problems because they are of the generation who may not have a good example from their parents and did not get proper financial education from their school. In the comparison with the results of the Ministry of Finance, there is a disproportion in the answer "I inform the creditors and try to close an agreement" 76:91 (students):51. This can, again, suggest further evidence of the impact of higher student education.

Following Figure 2 shows the results of the statistical analysis on data collected during research.

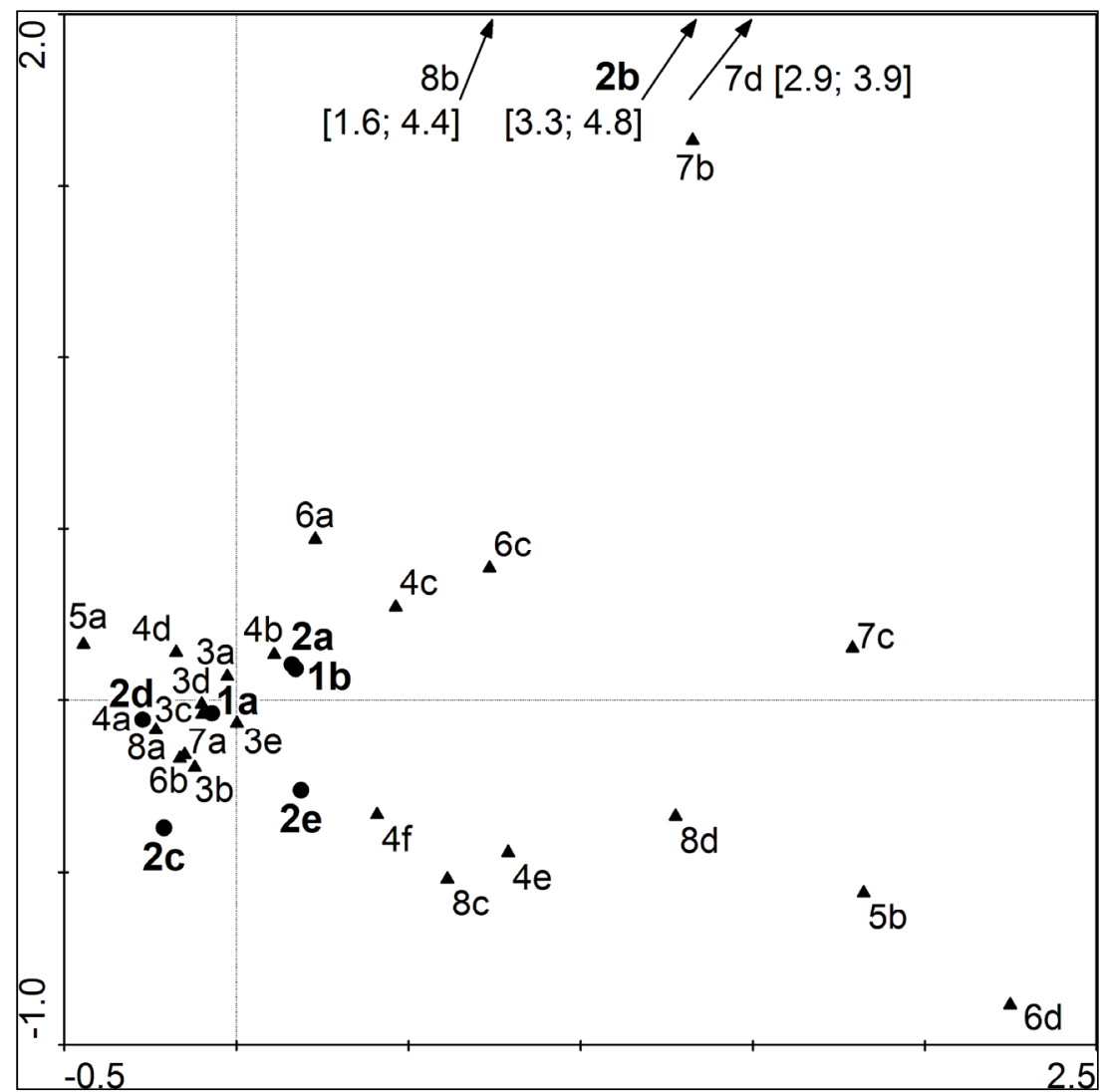

Figure 2. Analysis of the situation in the level of financial literacy by students. Source: author's own calculations.

The first two coordinating axes explain $23.5 \%$ of the variability (the first one $15.4 \%$ ). Triangular points express the active variable (economic behaviour of respondents) and the passive variables (sex and education of respondents). The image was somewhat scaled down and the position of three points lying outside of the viewable area is not shown but only described. It is possible to explain most of the variability by the level of financial literacy - by the knowledge or ignorance of some financial terms and the results of financial 
behaviour. In the left side, there are the answers which tend towards the meaning more "literate" (e.g., 5a, 6a, $6 \mathrm{~b}, 7 \mathrm{a}$, and $8 \mathrm{a}$ ), and on the right side more "illiterate" (5b, 6d, 7c, and $8 \mathrm{~b})$. Literate respondents had mostly the same answers; whereas, those on the illiterate side had answers that were different and variable. Answers with a low or very low level of financial literacy $(7 \mathrm{c}, 7 \mathrm{~d}$, and $8 \mathrm{~b}$ ) are in an upper part of the described area; while answers of hesitant respondents or those uncertain in the matters of finance (5b, 7b, and $8 d$ ) are at the bottom. Sex and education were not taken into account in the diagram because of no relation to the result.

The further researches are necessary to find the answers to the question if this situation could be caused by inadequate (time, quality) education or if it could be caused by the quality of educational process, too-for example there are not enough training and practical samples in the Czech educational system.

Some differences discovered on the age can be caused by own experiences of students in financial markets. Czech students start their independent life later and later as shown in the data collected by the Czech Statistical office, nowadays in 25.6 years.

\section{Conclusion}

Broadening the offer of financial services and their ever-growing complexity due to innovation and globalisation means that being financially knowledgeable is a "must have" skill for people nowadays. Increasing financial literacy triggers consequences on both the micro- and macro-economic levels. All of these have a clearly positive impact. On an individual scale, both personal and financial benefits can be observed. Personal consequences centre on social empowerment, whereas the financial ones stress the importance of financial education in both a reasonable use of financial products and in taking conscious decisions that relate to financial services. On the other side, macroeconomic consequences are reflected mainly in the reduction of financial exclusion and excessive indebtedness as well as in the restriction of efforts aimed at evening out existing disproportions in household incomes.

There is big space for some changes in legislation and transformation of banks and not banking institutions on the way to the transparent financial markets and changes in the moral obligations of start in any bank or fund or other financial enterprise - or official, or in the shadow. It will not be easy to work for any government, any central bank, and Basel Committee. It looks that economic and financial crisis meets the crisis of morality. The situation causes the need to teach and raises new generation by more sophistic methods and more practically. It is necessary to give lessons on practical topics in the connection with practice and not only on the theory about function of something.

What surprising is only the difference in time doing of the household budget and answers of very and not so much young students (age difference). The education and care home, in the family, are more matter than at the school. Education, gender, and even taking a financial course did not have a significant effect on participants' behaviour in this survey.

It can be assumed that family experience and parental guidance are the most frequent sources of information on how to manage and handle the finance. The correct model of financial behaviour, which includes discussion of the household budget and the preparation of financial strategies for a family by all its members, is very useful. In this situation, it can be big help on side of media, not only at schools.

\section{References}

Braak, C. J. F., \& Šmilauer, P. (2002). CANOCO, the statistical programme, version 4.5. 
Braak, C. J. F., \& Šmilauer, P. (2010). StatSoft, the statistical programme.

Lucas, D. J., Goodman, S. L., \& Fabozzi, F. J. (2007). Collateralized debt obligations and credit risk transfer. Journal of Financial Transformation.

Maroušek, J., Hašková, S., Zeman, R., \& Vaníčková, R. (2014). Managerial preferences in relation to financial indicators regarding the mitigation of global change. Science and engineering ethics. Springer Netherlands.

Ministry of education, youth and sports of the Czech Republic (MŠMT). (2007). Systém budování finanční gramotnosti na základních a středních školách/System of building of financial literacy at schools. Retrieved from http:/www.msmt.cz/vzdelavani/system-budovani-financni-gramotnosti-na-zakladnich-a-strednich-skolach?lang=1

Ministry of Finance of the Czech Republic/Národní strategie finančního vzdělávání. (2010). The National Strategy of Financial Education. Retrieved from http://www.mfcr.cz/cps/rde/xchg/mfcr/xsl/ft_strategie_financniho_vzdelavani_55251.html

Paseková, M., \& Ředinová, H. (2012). An explanatory study on the financial literacy of high school students in the Czech Republic. Proceedings of the 1st WSEAS International Conference on Finance, Accounting and Auditing (FAA 12), 20-22. September 2012, Zlín.

Renaud, B. M. (2009). Mortgage finance in emerging markets: Constraints and feasible development paths. In D. Ben-Shahar, C. K. Y. Leung, and S. E. Ong (Eds.), Mortgage markets worldwide. Blackwell Publishing Ltd.

Smrčka, L. (2008). Zadlužení rodin-Klíčové téma současnosti)/The key role of debts in Czech families. Ekonomika a Management, 2(1), 180.

The International Network on Financial Education (INFE). (2009). Retriieved from http://www.oecd.org/finance/financial-education/OECD_INFE_High_Level_Principles_National_Strategies_Financial_Educ ation_APEC.pdf

The Organisation for Economic Cooperation and Development (OECD). (2011). Measuring financial literacy: Questionnaire and guidance notes for conducting an internationally comparable survey of financial literacy. Retrieved from http://www.oecd.org/daf/financialmarketsinsuranceandpensions/financialeducation/49319977.pdf

VUP, RVP ZŠ. (2007). Rámcový vzdělávací program pro ZŠ/The programme of education for the Czech basic schools. Retrieved from http://www.vuppraha.cz/wp-content/uploads/2009/12/RVPZV_2007-07.pdf

Zandi, M. (2008). Financial shock. Upper Saddle River, N.J.: Financial Times Press. 